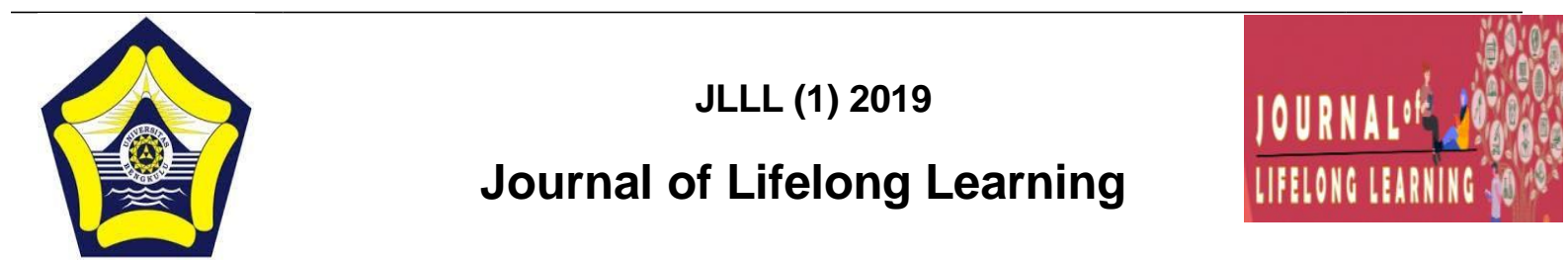

\title{
Pembelajaran Anak Berkebutuhan Khusus di PAUD Alam Bengkulu Mahira Kota Bengkulu
}

\author{
Yartika ${ }^{1}$, Agus ${ }^{2}$, Izzudin ${ }^{3}$ \\ ${ }^{1}$ Nonformal Education, University of Bengkulu, Indonesia, yartikaulandari@gmail.com \\ ${ }^{2}$ Nonformal Education, University of Bengkulu, Indonesia, aguszainal1823@gmail.com \\ 3 Nonformal Education, University of Bengkulu, Indonesia, mizzudin614@gmail.com
}

\begin{abstract}
This study aimed to find out the learning strategy of exceptional children in the Mahira Natural Kindergarten Bengkulu City. The method used is qualitative method with descriptive approach. Based on the result of the research and discussion, it is concluded that (1) the expectation / target in the learning of exceptional children are 7 development targets that are the the development of religious and moral values target, physical development target, cognitive development target, language development target, emotional social development target, self-building development target, and science development target. (2) Determination of the learning time allocation of exceptional children is within 1 week, it taken 1 hour to follow the learning activities in inclusion. For the rest, the exceptional children still followed the regular children learning. (3) Preparation of rewards/gift for exceptional children, there are three forms. First is physical form, such as food, snacks and toys. Second form is a gift / rewards given by the teacher in a verbal form, where gifts / rewards are given such as praise and motivation. Then the third gift / rewards in non verbal form such as hugs, thumbs up, applause, and tos together. (4) Provision of tasks / work for exceptional children. There are two forms of tasks. First is general task where general task form given same with the regular children, but the general task given still depends on the ability of the children itself. Second is a special task, where the task is designed specifically for exceptional children in accordance with the target of each children. (5) Provision of special assistance for exceptional children, there are three forms. First is physical assistance, where the assistance is provided directly to the exceptional children with direct physical touch. Then the second is verbal assistance, the help given such as teach the children to say hello, greet friends and say thank you. Then the third is emotional assistance, where the assistance is provided by helping to reduce emotions. (6) In the learning process, the themes and subjects given for the children are same, both for regular class and exceptional children. But different in the burden of learning given.
\end{abstract}

Keywords: Learning, Exceptionl Children, Mahira Natural Kindergarten Bengkulu 


\section{PENDAHULUAN}

PAUD Alam Bengkulu Mahira berdiri pada tahun 2006 dan telah teraktreditasi A pada tahun 2013. Sekolah Mahira terletak di Jalan Kini Balu, Nomor 11 Kebun Tebeng, Kota Bengkulu itu memberi warna baru pada dunia pendidikan di Provinsi Bengkulu. PAUD Alam Bengkulu Mahira adalah tempat yang sangat menyenangkan bagi anak-anak, seperti dunia fantasi, tempatnya belajar terkadang di taman hijau dengan pohon-pohon rindang, dan mereka lebih banyak menghabiskan waktunya diluar ruangan. PAUD Alam Bengkulu Mahira memiliki ciri khas yaitu: para murid lebih banyak belajar di alam terbuka, metode belajar mengajar lebih banyak menggunkan metode Action Learning, yaitu anak belajar melalui pengalaman. Penggunaan alam sebagai media belajar bertujuan agar murid lebih peduli dengan lingkungan dan bisa menerapkan pengetahuan yang dipelajari. Di PAUD Alam Bengkulu Mahira Kota Bengkulu juga menyelenggarakan program pendidikan inklusif.

Di PAUD Alam Bengkulu Mahira terdapat 6 anak yang berkebutuhan khusus dan dengan kategori Anak Berkebutuhan Khusus yang berbeda-beda, diantaranya adalah: 1. Afrin Almaira (gangguan konsentrasi), 2. Alisya Noverika (down syndrome), 3. Atha El Rafif (gangguan konsentrasi), 4. Fatir (gangguan bicara), 5. Jordan Arfa Mulyana (autis), 6. M. Ghaisan Danist (tuna rungu).

Maka disni peneliti ingin melihat strategi pembelajaran yang digunakan oleh guru kepada siswa tersebut khususnya untuk anak yang berkebutuhan khusus, karena didalam satu kelas itu terdapat anak yang berkebutuhan khusus dan juga anak normal yang belajar bersama-sama dalam satu kelas. Oleh karena itu, sebaiknya kita menggunakan strategi pembelajaran yang mendasarkan pada keberagaman kemampuan belajar anak yang berbeda-beda. Berdasarkan uraian diatas, maka penulis memandang perlu untuk mengadakan suatu penelitian mengenai "Strategi Pembelajaran Anak Berkebutuhan Khusus di PAUD Alam Bengkulu Mahira Kota Bengkulu"

Dilihat dari latar belakang penelitian rumusan masalah dalam penelitian ini adalah: 1) Apakah harapan/target dalam pembelajaran anak yang berkebutuhan khusus di PAUD Alam Bengkulu Mahira 2) Bagaimana guru menentukan alokasi waktu belajar anak yang berkebutuhan khusus di PAUD Alam Bengkulu Mahira. 3) Bagaimana guru menyiapkan penghargaan dan hadiah anak yang berkebutuhan khusus di PAUD Alam Bengkulu Mahira. 4) Bagaimana guru memeberikan tugas/pekerjaan anak yang berkebutuhan khusus di PAUD Alam Bengkulu Mahira. 5) Bagaimana guru memberikan bantuan tertentu kepada anak yang berkebutuhan khusus di PAUD Alam Bengkulu Mahira. 6) Bagaimana guru memberikan tema dan mata pelajaran yang sama dengan kelas yang ada anak berkebutuhan khusus di PAUD Alam Bengkulu Mahira?

\section{METODE}

Dalam penelitian ini sasaran yang dicapai dalam penelitian kualitatif diarahkan pada upaya menemukan teori-teori yang bersifat deskriptif. Peneliti menggunakan tipe deskriptif karena peneliti mencoba menggambarkan secara mendalam tentang strategi pembelajaran ank berkebutuhan khusus di PAUD Alam Bengkulu Mahira. Pada tipe ini peneliti akan melaksanakan wawancara, observasi, dan dokumentasi mendalam terhadap subjek penelitian dengan tujuan memperoleh informasi PAUD Alam Bengkulu Mahira.

\section{HASIL DAN PEMBAHASAN}

Harapan/target dalam pembelajaran anak yang berkebutuhan khusus di PAUD Alam Bengkulu Mahira terdapat 7 target perkembangan yaitu : pencapaian target perkembangan nilai 
agama dan moral, pencapaian target perkembangan fisik, pencapaian target perkembangan kognitif, target perkembangan bahasa, pencapaian target perkembangan sosial emosional, pencapaian target perkembangan bina diri, pencapaian target perkembangan sains.

Penentuan alokasi waktu belajar anak yang berkebutuhan khusus oleh guru di PAUD Alam Bengkulu Mahira terdapat tiga model pembelajaran yaitu yang petama anak reguler dan anak berkebtuhan khusus belajar bersama-sama dalam satu kelas, selanjutnya yang kedua yaitu anak berkebutuhan khusus belajar secara individu di ruang inklusi yang mana pembelajaran tersebut hanya berlangsung satu jam dalam satu minggu, kemudian yang ketiga yaitu semua anak berkebutuhan khusus di PAUD Alam Bengkulu Mahira berkumpul di ruang inklusi selama satu jam dan diperhatikan oleh Shadow teacher.

Penyiapan hadiah/penghargaan bagi anak berkebutuhan khusus oleh guru di PAUD Alam Bengkulu Mahira ada tiga bentuk yang pertama berbentuk fisik seperti makanan, snack, dan mainan, dimana hadiah tersebut diberikan oleh shadow teachernya dan biasanya hadiah diberikan dalam program kegiatan outbond. Kemudian bentuk kedua yaitu bentuk verbal, dimana hadiah/penghargaan yang diberikan seperti pujian dan motivasi. Kemudian yang ketiga yaitu hadiah/penghargaan berbentuk non verbal seperti pelukan, acungan jempol, tepuk tangan dan tos bersama.

Pemberian tugas/pekerjaan kepada anak yang berkebutuhan khusus oleh guru di PAUD Alam Bengkulu Mahira ada dua bentuk tugas yang pertama tugas umum dimana tugas yang diberikan sama dengan tugas yang diberikan kepada anak reguler, namun tugas umum yang diberikan tetap mempertimbangkan kemampuan anak berkebutuhan khusus, seperti tugas dikte, sholat dan bernyanyi. Selanjutnya yang kedua yaitu tugas khusus, dimana tugas tersebut memang dirancang khusus untuk anak berkebutuhan khusus sesuai dengan target masing-masing anak, seperti anak tunawicara dengan titik fokus pembelajaran huruf vokal, dan pembelajaran khusus dilakukan di ruang inklusi. Tugas umum dan tugas khusus yang diberikan tetap dibimbing oleh masing-masing shadow teacher anak. Pemberian bantuan tertentu kepada anak yang berkebutuhan khusus oleh guru di PAUD Alam Bengkulu Mahira ada tiga bentuk yaitu pertama bantuan secara fisik, dimana bantuan ini diberikan langsung kepada anak berkebutuhan khusus oleh shadow teacher dengan sentuhan fisik secara langsung seperti membimbing anak belajar berjalan dengan memegang tangannya, membantu anak memakai baju dan lainnya. Kemudian yang kedua bantuan secara verbal yaitu bantuan yang diberikan melalui kata-kata misalnya mengajarkan anak mengucap salam, menyapa teman dan berterima kasih. Selanjutnya yang ketiga bantuan secara emosional, dimana bantuan diberikan dengan cara memberikan arahan yang baik, memberikan pengertian, membantu meredamkan emosi dan berusaha menenangkan anak tersebut serta memberikan sebab akibat dari segala bentuk perbutan.

Pemberian tema dan mata pelajaran yang sama dengan kelas yang ada anak berkebutuhan khusus oleh guru di PAUD Alam Bengkulu Mahira maksudnya yaitu dalam proses pembelajaran tema dan mata pelajaran yang diberikan kepada anak sama, baik bagi anak reguler maupun anak berkebutuhan khusus. Namun berbeda dalam beban pembelajaran yang diberikan seperti tema tumbuhan, bagi anak reguler diberikan beban mengenai jenis, warna, bentuk, dan bagian-bagian, sedangkan bagi anak berkebutuhan khusus disesuaikan dengan keemampuan dan kesanggupan anak.

\section{PENUTUP}

KESIMPULAN 
Berdasarkan hasil wawancara, observasi dan dokumentasi, adapun hasil analisis data mengenai strategipembelajaran anak berkebutuhan kusus di PAUD Alam Bengkulu Mahira, sebagai berikut:

1. Harapan/target dalam pembelajaran anak yang berkebutuhan khusus di PAUD Alam Bengkulu Mahira terdapat 7 target perkembangan yaitu : pencapaian target perkembangan nilai agama dan moral, pencapaian target perkembangan fisik, pencapaian target perkembangan kognitif, target perkembangan bahasa, pencapaian target perkembangan sosial emosional, pencapaian target perkembangan bina diri, pencapaian target perkembangan sains.

2. Penentuan alokasi waktu belajar anak yang berkebutuhan khusus oleh guru di PAUD Alam Bengkulu Mahira terdapat tiga model pembelajaran yaitu yang petama anak reguler dan anak berkebtuhan khusus belajar bersama-sama dalam satu kelas, selanjutnya yang kedua yaitu anak berkebutuhan khusus belajar secara individu di ruang inklusi yang mana pembelajaran tersebut hanya berlangsung satu jam dalam satu minggu, kemudian yang ketiga yaitu semua anak berkebutuhan khusus di PAUD Alam Bengkulu Mahira berkumpul di ruang inklusi selama satu jam dan diperhatikan oleh Shadow teacher.

3. Penyiapan hadiah/penghargaan bagi anak berkebutuhan khusus oleh guru di PAUD Alam Bengkulu Mahira ada tiga bentuk yang pertama berbentuk fisik seperti makanan, snack, dan mainan, dimana hadiah tersebut diberikan oleh shadow teachernya dan biasanya hadiah diberikan dalam program kegiatan outbond. Kemudian bentuk kedua yaitu bentuk verbal, dimana hadiah/penghargaan yang diberikan seperti pujian dan motivasi. Kemudian yang ketiga yaitu hadiah/penghargaan berbentuk non verbal seperti pelukan, acungan jempol, tepuk tangan dan tos bersama.

4. Pemberian tugas/pekerjaan kepada anak yang berkebutuhan khusus oleh guru di PAUD Alam Bengkulu Mahira ada dua bentuk tugas yang pertama tugas umum dimana tugas yang diberikan sama dengan tugas yang diberikan kepada anak reguler, namun tugas umum yang diberikan tetap mempertimbangkan kemampuan anak berkebutuhan khusus, seperti tugas dikte, sholat dan bernyanyi. Selanjutnya yang kedua yaitu tugas khusus, dimana tugas tersebut memang dirancang khusus untuk anak berkebutuhan khusus sesuai dengan target masing-masing anak, seperti anak tunawicara dengan titik fokus pembelajaran huruf vokal, dan pembelajaran khusus dilakukan di ruang inklusi. Tugas umum dan tugas khusus yang diberikan tetap dibimbing oleh masing-masing shadow teacher anak.

5. Pemberian bantuan tertentu kepada anak yang berkebutuhan khusus oleh guru di PAUD Alam Bengkulu Mahira ada tiga bentuk yaitu pertama bantuan secara fisik, dimana bantuan ini diberikan langsung kepada anak berkebutuhan khusus oleh shadow teacher dengan sentuhan fisik secara langsung seperti membimbing anak belajar berjalan dengan memegang tangannya, membantu anak memakai baju dan lainnya. Kemudian yang kedua bantuan secara verbal yaitu bantuan yang diberikan melalui kata-kata misalnya mengajarkan anak mengucap salam, menyapa teman dan berterima kasih. Selanjutnya yang ketiga bantuan secara emosional, dimana bantuan diberikan dengan cara memberikan arahan yang baik, memberikan pengertian, membantu meredamkan emosi dan berusaha menenangkan anak tersebut serta memberikan sebab akibat dari segala bentuk perbutan. Pemberian tema dan mata pelajaran yang sama dengan kelas yang ada anak berkebutuhan khusus oleh guru di PAUD Alam Bengkulu Mahira maksudnya yaitu dalam proses pembelajaran tema dan mata pelajaran yang diberikan kepada anak sama, baik bagi anak reguler maupun anak berkebutuhan khusus. Namun berbeda dalam beban pembelajaran yang diberikan seperti 
tema tumbuhan, bagi anak reguler diberikan beban mengenai jenis, warna, bentuk, dan bagian-bagian, sedangkan bagi anak berkebutuhan khusus disesuaikan dengan keemampuan dan kesanggupan.

\section{REFERENSI}

Delphie, Bandi. 2009. Pembelajaran Anak Berkebutuhan Khusus dalam setting Pendidikan Inklusi. Klaten: PT Intan Sejati Klaten.

Darmadi, Hamid. 2014. Metode Penelitian Pendidikan dan Sosial, Teori Konsep Dasar dan Implementasi. Bandung: Alfabeta.

Hidayat. Model dan strategi pembelajaran $A B K$ dalam setting Pendidikan Inklusif http://puterakembara.org/BPP/Makalah1.pdf diakses pada tanggal 20 Maret 2018 pukul 20:35

https://saifias.wordpress.com/2012/11/05/strategi-pembelajaran-bagi-anak-berkebutuhan-khusus/ diakses pada tanggal 26 Maret 2018 pukul 21.24

http://achmadblue.blogspot.co.id/2011/03/bimbingan-anak-berkebutuhan-khusus.html

http://izzaucon.blogspot.com/2014/06/klasifikasi-anak-berkebutuhan-khusus.html diakses pada tanggal 6 Juli 2018 pukul 20.00

Kamil, Mustafa. 2011. Pendidikan Non Formal, Pengembangan Melalui Pusat Kegiatan Belajar Masyarakat (PKBM) di Indonesia (Sebuah Pembelajaran Dari Kominkan Jepang). Bandung: Alfabeta.

Kamus Besar Bahasa Indonesia terbitan Departemen Pendidikan dan Kebudayaan. 1991. Jakarta: Balai Pustaka. Diakses dari

http://belmy.info/pengertian-pencapaian-target-menurut-ahli.html

Komara. Endang. 2014. Belajar dan Pembelajaran Interaktif. Bandung: PT. Refika Aditama.

Marzuki. Saleh, 2010. Pendidikan Non Formal, Dimensi Dalam Keaksaraan Fungsionl, Pelatihan dan Andaragogi.

Bandung: PT Remaja Rosdakarya

Nata. Abuddin. 2014. Perpspektif Islam Tentang Strategi Pembelajaran. Jakarta: Kencana.

Nugraheni. 2012. Menentukan Alokasi Waktu. Diakses dari digilib.unila.ac.id/14852/2/bab\%202.pdf

Prastowo. Andi. 2017. Menyusun Rencana Pelaksanaan Pembelajaran (RPP) Tematik Terpadu. Jakarta: Kencana

Purwanto. 2011. Pengertian Reward. Diakses dari http://repository.ump.ac.id/52/3/BAB\%20II.pdf

Purwanto. Heri. 1998. Pengantar Perilaku Manusia Untuk Keperawatan. Jakarta: EGC.

Sanjaya, wina. 2006. Strategi Pembelajaran Berorientasi Standar Proses Pendidikan. Jakarta: Kencana Prenada Media 
Somad. Permanarian. 1996. Ortopedagogik Anak Tunarungu. Jakarta: Depdikbud RI

Santoso, H. 2012. Cara Memahami dan Mendidik Anak Berkebutuhan Khusus. Yogyakarta: Gosyen Publishing

Sudarsini. 2017. Bina Diri Bina Gerak. Malang: Gunung Samudera

Sudjana, Djudju. 2001. Pendidikan Non Formal: Wawasan, Sejarah Perkembangan, Falsafah, \& Teori Pendukung, serta Asas. Bandung: Falah Production.

Sugiyono. 2006. Metode penelitian kuantitatif kualitatif dan $R \& D$. Bandung: Alfabeta

Sugiyono. 2013. Metode Penelitian Kuantitatif Kualitatif dan R\&D. Bandung: CV. Alfabeta.

Sujiono, YN. 2009. Konsep Dasar Pendidikan Anak Usia Dini. Jakarta: PT INDEKS

Rusman. 2017. Belajar dan Pembelajaran Berorientasi Standar Proses Pendidikan. Jakarta: Kencana

Yuwono, Joko. 2009. Memahami Anak Autistik (Kajian Teoritik dan Empirik). Bandung: Alfabeta

www.islamkuno.com/2008/01/27/metodestudikasus diakses pada tanggal 24 maret 2018 